Jurnal The Messenger, Vol. 11, No. 1A, Special Issue on the School of Multimedia Technology and Communication Postgraduate Symposium, pp. 94-110

\title{
Leadership Communication Conception of Malaysian Hindus and its Relevancy to Mahathir's Leadership
}

\section{Konsepsi Komunikasi Kepemimpinan Malaysia Hindu dan Relevansinya dengan Kepemimpinan Mahathir}

\author{
S Maartandan a/l Suppiah ${ }^{1}$, Mohd. Khairie Ahmad ${ }^{2}$, Norhafezah Yusof ${ }^{2}$ \\ ${ }^{1}$ Department of Public Relations, Faculty of Arts and Social Science, Universiti Tunku \\ Abdul Rahman, Bandar Barat, 31900 Kampar, Negeri Perak, Malaysia \\ ${ }^{2}$ School of Multimedia Technology and Communication, Universiti Utara Malaysia, \\ Sintok, Kedah, Malaysia \\ *Corresponding author, e-mail: maartandan@utar.edu.my
}

\begin{abstract}
Literatures proposed that culture does influence the success of leadership communication. Mahathir was criticised to be a leader who promotes the betterment of the majority community and marginalised the Indians. Despite of that, the Indians in Malaysia showed advancement in various sectors including politics, economy and social. Therefore, this exploratory study aims to bridge the gap by investigating the attributes that link between Mahathir's leadership communication and Indian community. Qualitative methodology was utilized and data were collected through a series of intensive interviews with 15 informants consists of Indian political, non-governmental organisation and community representatives. Based on the thematic analysis, two main attributes that strongly link to Indian culture were identified: leadership communication conception (Sattva Guna) and characteristics of good leadership communication (Sattva characteristics). This study has contributed to enhance understanding of leadership communication from multi-cultural context, specifically about the Indian's cultural conceptions. Keywords: Social Change, Culture Sensitivity, Minority, Inter-ethnic Leadership Communication.
\end{abstract}

\begin{abstract}
Abstrak
Literatur mengemukakan bahwa budaya mempengaruhi keberhasilan komunikasi kepemimpinan. Mahathir dikritik sebagai pemimpin yang mempromosikan perbaikan komunitas mayoritas dan memarginalkan orang India. Meskipun demikian, orang India di Malaysia menunjukkan kemajuan di berbagai sektor termasuk politik, ekonomi dan sosial. Oleh karena itu, penelitian eksplorasi ini bertujuan untuk menjembatani kesenjangan dengan menyelidiki atribut yang menghubungkan antara komunikasi kepemimpinan Mahathir dan komunitas India. Metodologi kualitatif digunakan dan data dikumpulkan melalui serangkaian wawancara intensif dengan 15 informan yang terdiri dari perwakilan politik komunitas India, organisasi nonpemerintah dan masyarakat. Berdasarkan analisis tematik, dua atribut utama dalam penelitian, diidentifikasi sebagai: konsepsi komunikasi kepemimpinan (Sattva Guna) dan karakteristik komunikasi kepemimpinan yang baik (karakteristik Sattva). Studi ini berkontribusi untuk meningkatkan pemahaman tentang komunikasi kepemimpinan dari konteks multi-budaya, khususnya mengenai konsepsi budaya India.
\end{abstract}

Kata Kunci: Perubahan Sosial, Sensitivitas Budaya, Minoritas, Komunikasi Kepemimpinan antar Etnis.

Article History: Received April 26, 2018; Revised May 16, 2019; Accepted May 24, 2019; Published June 02, 2019 


\section{Introduction}

Researches on transformational leadership theory for more than twenty-five years proved the effect of transformational leadership on followers' attitude and behaviours (Mhatre \& Riggio, 2014) and it was evident that there is sufficient conceptual gap in understanding the functionality of transformational leadership theory (Fairhurst \& Connaughton, 2014; Van Knippenberg \& Sitkin, 2013; Yukl, 2006) However, it was found that research investigating the transformational leadership theory from a contextual perspective was still underdeveloped, specifically the type of leaders' behaviour in a cultural context and how does it affects followers was still not fully explored (Ayman \& Korabik, 2010). Consistent with the idea, Burns (1978) indicated that transformational leadership theory which explains the quality of a leader who possesses cultural knowledge of his followers will be able to promote the betterment among followers. Further, Singh and Bhandarker (1990) also strongly asserted that the change in society by a leader would be successful when a leader able to identify the culture of his or her followers.

It was further supported by Kanungo and Misra (2004) who stated that transformational leadership is influenced by culture. However, it was apparent that fewer studies have been conducted focusing on transformational leadership theory on the cultural context, specifically exploring transformational leadership theory in a multicultural context (Lynn-Sze \& Ahmad, 2017; Yukl, 2006). Studies conducted mainly focused on western based context and treated the society as homogenous, such as GLOBE study (Hofstede \& Minkov, 2010). However, scholars argued that the leadership outcome varies across cultural context or heterogeneous society. For instance, Graen (2006)criticizes the multicultural perspective that was overlooked in GLOBE study. This is consistent with the discussion by Bass, (1990); Chemers and Ayman (1993) who stated that leadership prototypes and conceptions vary from one culture to another and they have dramatically brought different implications in different multicultural contexts. Andreouli (2013) also pointed out that many researchers failed to discuss the diversity of society. Indeed, it shows the need to explore transformational leadership theory in a multi-cultural context or heterogeneous society. Hence, this study provides a new dimension to leadership communication from multi-cultural context, specifically leadership communication involving two communities of difference cultures. It is important to investigate leadership communication in a multi-cultural country because culture and religion of communities plays an important role in creating differences between different ethnic groups in countries like Malaysia (Beyer, 1999).

Literatures proved that a leader could successfully bring some developments in society if he or she could communicate successfully with his or her followers through a good understanding of cultural values of followers (Hofstede \& Hofstede, 2005). This is because a leader would be able to understand his or her follower's needs and requirements and fulfill them accordingly. Thus, this study viewed culture as an important element in drive changes in society. Based on Bass (1999), it was understood that through the shared goals set by a leader, a leader able to influence followers. Lord, Brown, and Freiberg (1999) also emphasised that leaders could affect followers' attitude and behaviour by influencing their values. By understanding the relationship between leadership communication and culture, this explores Mahathir's leadership communication in Malaysia from Indians cultural perspective.

In general, there were many studies conducted to analyse the assumptions of leadership theories but most focusing on western countries (Beyer, 1999; Lynn-Sze, Yusof, \& Ahmad, 2014). However, the cross cultural studies proved that not all the

Jurnal The Messenger, Vol. 11, No. 1A, Special Issue on the School of Multimedia Technology and Communication Postgraduate Symposium, pp. 94-110 
assumptions of the theories are applicable to all cultures in the world (Hofstede, 2001; Smith \& Peterson, 2002). Studies proved that different leadership style produce different outcomes in different cultural context (Paramova \& Blumberg, 2017; Smith \& Peterson, 2002) Furthermore, in the best knowledge of the researcher, there were fewer studies has been conducted relating to leadership communication and cultural perspective. Hence, it is important to investigate Mahathir's leadership communication from the Indian religion (Hinduism) perspective which could provide a new dimension in leadership communication studies in the Indians' cultural perspective. Also, House and Aditya (1997) claimed that there were more than 3000 studies listed by Bass (1990) mainly focused on the relationship between leaders and their immediate followers, however those studies neglected the aspect of cultural context and the rapport of leaders and followers who belong to different culture.

Since the independence in 1957, Malaysian politics were based by ethnicity (Ayodurai, Yahaya, \& Zainuddin in Bhopal and Rowley, 2005) Malaysia is a country with a multiracial society. The government always provides a special care and attention to the issues related to different ethnicity, and as an evident, government implemented culture based public policy to avoid any racial conflict to create a positive environment (Gudykunst \& Nishida, 2001; Hall \& Lord, 1995). In contrast, after the 1969 race riots, a manifestation of inter-ethnic conflict over the distribution of political and economic power, there was ethnocentric development characterised by a National Ideology (Rukunegara), attempting to create a basic consensus on communal issues to constrain the more extreme demands of some ethnic groups (Means, 1991). It is evident that culture plays an important role which could be seen through the existence of specific-ethnic based political parties which represent different cultural groups such as Malayan Indian Congress (MIC), United Malaya National Organisation (UMNO) and Malayan Chinese Association (MCA) (Dahles \& Leng, 2014).

Cultural sensitivity or inter-ethnic relations is a major challenge to the social stability of Malaysia (Baharuddin, 2005; Taman \& Krauss, 2017). Mahathir as the longest serving Prime Minister has been viewed as a leader who was more concerned with the majority community (Malay communal) that he represented and marginalized the Indian communal in Malaysia (Kailasam, 2015; Wain, 2012). However, interestingly, despite many issues under the leadership of Mahathir, the Indian community in Malaysia recorded improvements in various fields (see Table 7 Incidence of Poverty by Ethnic Group, Strata and State, Malaysia, 1970-2014, for complete data) and secondly, the cultural sensitivity among non-Muslim towards Muslims was better (Saad, 2012). This situation could be explained through leadership communication theories such as transformational leadership theory which explains that culture play an important role in facilitating the leadership communication process between leader and follower, for instance, the quality of a leader who possesses cultural knowledge of his followers will be able to promote betterment of followers (Bakar, Jian, \& Fairhurst, 2014; Kanungo \& Misra, 2004). Lynn-Sze et al. (2014) also strongly asserted that the change in society by a leader would be successful when a leader is able to identify the culture of his or her followers. Present studies found that Indian philosophy provides a clear understanding of an individual's mental make-up which could be explained through Vedanta philosophy. The philosophy explains that different people have different qualities that influence their attitudes and behaviors in daily life (Davis, 2014).

Besides that, it was found that there were many researches relating Islamic conception and leadership conducted by Tayeb (1997), Beekun and Badawi (2005); 
Abuznaid (2005). And studies relating Chinese philosophy and leadership were also conducted relating to Confucius, Lao Tzu \& Sun Tzu (Art of War) (Muniapan, 2006). Furthermore, there are also ample of researches on Mahathir's leadership focusing on various perspectives conducted since 1990 (Ahmad Atory, 1997; Rusdi \& Sivamurugan, 2006) However, it was apparent that research works in analysing modern leadership practices from the communication and Indian cultural perspectives are indeed limited (Muniapan, 2006). Therefore, this study is expected to fill in the gap by exploring Mahathir's leadership communication from the Indians' cultural(religion) perspective; hence this study could enrich and contribute to the body of knowledge, leadership communication by providing some references to the society, specifically the leaders to understand and manage a minority community towards social change.

Literature Review

Culture is viewed as an on-going recreation of meaning and it is within an individual (Gardenswartz, Rowe, A., Digh, \& Bennett, 2003). This idea is consistent with the concept of leadership communication which refers to the process of creating meaning. Thus, culture and leadership communication are bound together, and a leader creates and adapts to the culture (Barrett, 2014).

According to Singh and Krishnan (2007) leadership communication is classified as a social phenomenon, thus, leadership communication is relevant to be explored in conjunction with culture. They also argued that leaders need to be sensitive towards different cultural background of their followers to ensure the needs and requirements of the followers are fulfilled (N. Singh \& Krishnan, 2007). Bass (1997) also stated that different behaviours were exhibited by leaders in different cultures. Hence, it is very important for a leader, especially for a transformational leader to be able to adapt their behavior according to different cultural context.

The ability to be sensitive towards different cultures is a very important component of leadership communication, specifically for a transformational leader. Hofstede (1980) stated that a culture consists of different aspects and layered phenomenon within which 'the collective programming of the human mind occurs' (Hofstede, 1980). He had identified the link between culture and work-related values. Further, in terms of transformational leadership, he discussed three major elements of transformational leadership which are charisma, individualised consideration and intellectual stimulation, which could influence the culture of a leader's followers (Hofstede, 1983).

Besides Ergeneli, Gohar, and Temirbekova (2007) explored the relationship between transformational leadership and Hofstede's (cultural dimensions). Their findings strengthened the study conducted by Bass and Avolio (1994) and concluded that transformational leadership is suitable across various cultures. Furthermore, leadership communication scholars also argued that a good understanding of followers' culture is very important for a leader to create a strong relationship with followers and gain their strong support (Krishnan, 2002). Leaders also need to establish shared visions for the followers as a guiding principle, which means leaders must be able to create a strong meaning for their followers (Bass, 1990). Thus, this study argues that Mahathir reflected transformational leadership qualities; he introduced and implemented visions and show high commitments and efforts in transforming Malaysians, particularly the Indians to betterment. Regards to that, Mahathir was perceived as a leader who was sensitive towards the culture of his followers, including the Indians, and brought some improvements in Indian community in Malaysia.

Jurnal The Messenger, Vol. 11, No. 1A, Special Issue on the School of Multimedia Technology and Communication Postgraduate Symposium, pp. 94-110 
Furthermore, a study was conducted by Jung and Avolio (1999) comparing transformational and transactional leadership styles in a cross-cultural context. One of the recent studies related to culture and leadership was conducted by Paulienè (2012) found that the cultural values of followers and leaders influence leadership communication process which emphasised on culture-specific behaviours. Scholars also have examined the relationship between type of culture and the effectiveness of leadership. For instance, Pauliene, (2012) found that Australian and Turkish cultures also advocate for a cordial leader-follower relationship under a transformational leadership style. The transformational leader was regarded as a coordinator who promotes a healthy environment among followers Paulienè (2012). It clearly indicates that cultural knowledge of leaders contributes to effective leadership communication. In another study conducted by Markus and Kitayama (1991) stated that cultural factors affect the basic processes underlying leadership relations. Likewise, leadership prototypes and conceptions vary from one culture to another (Bass, 1990), and they have dramatically brought different implications in different cultural contexts (Ensaria \& Murphy, 1999). It means a leader needs to understand and fulfill the cultural needs of his or her followers in persuading followers towards social change or shared goals. The cultural context in which a leader and followers interact has strongly influenced the their communication process, especially in a country of multi-ethnic society such as Malaysia. Thus, the next section will discuss the Indian culture and its relationship with leadership communication.

Since the publication of Hofstede's book in 1980, the influence of culture on the attitude and behaviours of individual gained attention from various researchers (Mohd. Yusoff, Roselina, \& Syed Azizi, 2002). Hofstede identified many cultural dimensions and continued to replicate his study across many countries until 2010 with 76 researches on the topic (Hofstede \& Minkov, 2010). However, Hofstede (1991) treated Malaysian as a homogenous society by ignoring the different ethnic compositions which made his study questionable. To counter his studies, some follow-up studies were conducted by local researchers showed that each ethnic group is diverse and unique (Mohd. Yusoff et al., 2002).

To further understand the effects of culture on leadership communication process, literature related to the GLOBE (Global Leadership and Organizational Behaviour Effectiveness Research Program) study is explored. One of the questions that was investigated under the GLOBE Study was to what extent do the cultural forces influence the expectation of individuals on the leaders and their behaviour and to what extent will leadership study vary consistently with culturally specific values and expectations. In short, the GLOBE study focuses on the effects of cultures on the practice of leadership across cultures in the world. However, similar to Hofstede's studies, the 10 year research programme of (GLOBE) treated Malaysia as a homogenous country which neglected the cultural values hold by each ethnic group in the country. The GLOBE study assumed that there is no significant relationship between the different ethnic groups in Malaysia (Kennedy, 2002). Graen (2006) criticised that the GLOBE study has overlooked the cultural diversity element in the country. It is importance of culturally inclusive research to expand related theories and seek in-depth knowledge in cultural context. Therefore, Dahlia (2008) encourages future researchers to conduct research to understand the cultural values between different cultural groups in Malaysia. Consistent with the idea, more researches focusing on cultural difference between different ethnic groups have been conducted, such as Asma and Lim (2001) found that religious values of different ethnic groups creates a significant difference in attitude and behaviour between ethnic 
groups in Malaysia. This clearly indicates that the attitude and behaviour of people depends on their culture and so is leadership (Hofstede, 1991; Mohd. Yusoff et al., 2002) Furthermore, cultural values significantly influence leadership process such as the preferred leadership style (Mohd. Yusoff et al., 2002). Thus, the present study is unique as it aims to investigate leadership communication from the Indian cultural perspective.

Malaysia is a multicultural country consists of three main ethnic groups, each has its own cultural practices and values, but living in a harmonious environment (Asma, 1992). Abu Bakar and McCann (2014) stated that though Malaysians who come from different cultures and religions continue to exchange influences and ideas, each community or ethnic group is different from one another. Thus, sensitivity to cultural diversity is important to promote a positive environment and development in Malaysia (Chen \& Van Velsor, 1996). According to Wibbeke (2010), a leader with good intercultural communication will be comfortable with any differences that persist in society, especially, in terms of race, ethnicity, culture and belief. The scholar argued that a leader with good intercultural competency possesses knowledge about their social impact on others. Thus, this study perceives culture (religion) as an integral element in leadership communication that bridges the leadership communication between leaders and followers of different ethnic groups. Therefore, in order to communicate effectively, leaders need to understand followers' cultural value as culture has a great influence on followers (House \& Aditya, 1997; Paramita \& Carissa, 2018). This element makes leadership communication more dynamic, this study suspects there is a common or shared culture among Indians that made them to accept Mahathir's leadership. This assumption perceived to be consistent with studies conducted by Asma and Singh, (1992) in Malaysia indicated that ethnic groups in Malaysia have different preference towards leadership. Based on the findings of their study, it was discovered that Indians look forward to have impartial boss-centered leadership, the Chinese want to have a trustworthy leader and Malays prefer a social-centric leader.

In the previous sections, the link between leadership communication and social change, and, leadership communication and culture were explored. Culture contributes to the effectiveness of leadership because it depends on the understanding of a leader towards the needs of the followers (House \& Aditya, 1997). According to Bass (1997), although transformational leadership is universal, in order to be transformational, a leader would act differently in different cultural context. This is because culture influences the four components of transformational leadership which are manifested in a leader's behavior. For instance, a study by Ardichvili and Gasparishvili (2001) discussed that transformational leadership model was the most suitable in four USSR countries. Besides that, articulation of vision which was one the fundamental component of transformational leadership shown to be culturally related varying from public oratory skills in USA to public service by Mother Teresa in India (Smith \& Peterson, 2002). Bass (1999) conceded that transformational leadership is authentic because it is incorporating the cultural component which is the fundamental of the leadership. Scholars such as Kanungo and Misra (2004); Khandwalla (1990), argued that transformational leadership is significant in developing countries such as India. This is because transformational leader could address the needs of the follower and stimulate change in society by identifying the unique culture of the followers. Consistent with the idea, Singh and Bhandarker (1990) stated that the change in society by a leader would be successful when a leader is able to identify the cultural sensitivities in the society.

Jurnal The Messenger, Vol. 11, No. 1A, Special Issue on the School of Multimedia Technology and Communication Postgraduate Symposium, pp. 94-110 
Relating to Indian culture and transformational leadership, according to Krishnan (2002), the Indian culture is facilitating the development of transformational leadership. The Indian civilization is one of the oldest civilisations in the world existing for more than 5000 years and the contribution of India and Indians to this world various fields of knowledge is remarkable. For instance, many ancient literatures such as the 'Valmiki Ramayana', the 'Mahabharata' (includes the 'Bhagavad-Gita'), provide leadership lessons that are relevant to be applied into modern context. Consistent with that, Panda and Gupta (2007) also indicated that leadership studies should focus on development of specific leadership models, which revolve around Indian cultural roots and values. Furthermore, researchers have attempted to explain the relationship between culture and leadership (Choong \& Thomas, 1997; Leslie \& Van Velsor, 1998). In addition, the scholar has stressed on the need to explore Indian ancient philosophies in the context of modern times (Chinmayanda, 2003). In line with the idea, a study has been conducted by Muniapan (2007) to examine transformational leadership and Valmiki Ramayana (ancient literature) which provide discussion about transformational leadership based on Indian philosophy. Thus, this study expected to relate the Indian philosophy in this context of study specifically focusing on Mahathir's leadership communication which was an evident gap to be filled in. Thus, the present study aimed to explore Mahathir's leadership communication by exploring ancient Vedic literatures (such as Valmiki Ramayana and Bhagavad-Gita) to understand the influence of Indians' religion philosophy.

As evidence, in studies conducted by Engardio and McGregor (2006), it was stated that there are various leadership lessons can be found in the ancient Indian scriptures; Bhagavad-Gita and Ramayana and many top business schools in the United States have introduced 'self-mastery classes' by using Indian philosophy aimed to improve students' leadership skills in Rarick \& Nickerson (2008). The Bhagavad-Gita is stated as one of the oldest ancient texts in the world which consists of many leadership lessons.

\section{Methodology}

This study employed the qualitative method to examine the way the Indians perceive leadership communication from the Indian cultural (religion philosophy) perspective. This study posited that qualitative methods enable research studies to capture the complexity of leadership and follower dynamics, including the cultural context (Gordon \& Yukl, 2004). In order to get a holistic perspective on leadership communication from Indians cultural perspective, 15 research informants who are Indian political leaders, non-governmental organisation and community representatives were selected using purposive sampling was used based on recommendation by Patton (2002). Based on the recommendation, this study follows the process of selecting informants of the study. Firstly, this study identified the individual who had experienced the phenomena particularly, the Indians who had experienced Mahathir's leadership (1981-2003). There are a few other criteria involved in selecting the informants of the study; the informants should be Indians, second, they should be a representative of different organisation. They were identified through online search, popularity, peoples' suggestions and contacts.

Second step, is gaining access to the informants which involve several steps. After conducting the background research of the informants, the researcher contacted the informants who are suitable to fulfill the purpose of the study. After identifying the candidate, the researcher approached the candidate via phone. Upon verbal consent, an email was sent to the candidate along with the informant consent form, interview protocol 
and information sheet of the research. Once written consent obtained from the candidate, further arrangement for the interview session was made such as fixing time, date and location of the interview. Upon the arrangement, the informants were interviewed.

All interviews were tape-recorded and transcribed. Each interview session lasted between 45 to 60 minutes and proceeded until the data had been saturated. After obtaining informant consent, each informant was asked to verbally respond to the questions on interview protocol. The informants were asked to share their experiences about Mahathir's leadership communication from the Indian cultural perspective.

Thematic analysis was used to identify, analyse and create a theme for the data collected. Three stages of thematic analysis which are data coding stage, themes developing stage and analytical theme creating stage were applied (Thomas \& Harden, 2008). The researcher also used probing questions and created a state of epoche (Amerson, 2011; Bucic, Robinson, \& Ramburuth, 2010; Simbolon, 2012). To further enhance data saturation, as per the recommendation of Bernard (2012), this study interviewed informants from various groups such as, Indian political, non-governmental organisation and community representatives. This is to avoid one particular individual who specialized in a field to overshadow the data.

\section{Results and Discussion}

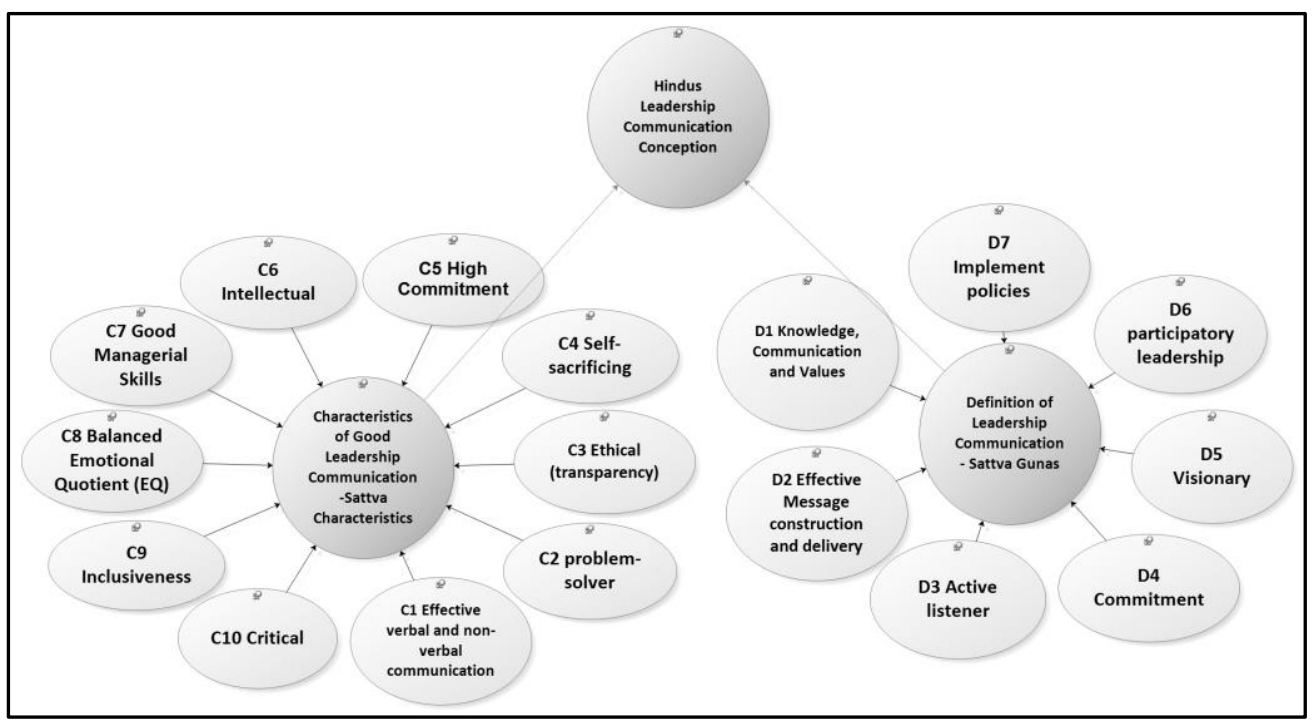

Figure 1. Indians Leadership Communication Conception (source: Author's Analysis)

This section provides the results of data analysis obtained from the data collected from 15 informants. The study aims is to investigate the responses of Indians towards the leadership communication conception and its relevancy to Mahathir leadership communication from the Indians' cultural perspective. The data has been analysed using the NVivo software and the figure above was constructed. Figure 1 shows that there are two themes that could explain the Indians' leadership communication conception.

Hindus Definition of Leadership Communication

Based on the findings of the present study, the Indians have indicated three main ideas in defining leadership communication which are positive attitude, effective communication skills, and leadership style. Discussing positive attitude, the study found that fulfilment of promises and being ethical as important components of leadership communication. A leader need to deliver his promises to the people and nation, and need

Jurnal The Messenger, Vol. 11, No. 1A, Special Issue on the School of Multimedia Technology and Communication Postgraduate Symposium, pp. 94-110 
to be an ethical leader. Secondly, in terms of effective communication skills, leadership communication involves effective communication between a leader and followers, including the establishment and articulation of vision for the society and nation, be an active listener, and able to construct and deliver messages effectively. Third, the leadership style. The finding of the present study pointed out that leadership communication involves participatory leadership style which encourages the participation of people in the leadership communication process. Relating the definition of leadership communication provided by the informants to the definition provided by Barrett (2014) who defined leadership communication as a purposeful process of transferring meaning aimed to influence people through effective communication skills and establish positive relationship with the followers by motivating and inspiring them. Analysing the definition provided by Barrett (2014) there are three main components of leadership communication which found to be consistent with the definition reported in the present study; transferring meaning (communication skills: translating visions), establish positive relationship (positive attitude: fulfil promises to the people) and motivate followers to achieve shared goals (leadership style: participatory leadership).

Relating to Bhagavad-Gita, it has categorised people based on three attributes (Gunas); 'sattva', 'rajas' and 'tamas' (Chinmayanda, 2003). According to the BhagavadGita, the interactions of these three attributes (Gunas) contribute to the creation of mental make-up of an individual. In general, 'Sattva Guna' is referring to the qualities of an individual who work for betterment of the people and they are self-less. They are sensitive to others' needs and work towards shared goals. 'Rajas Guna' is referring to the qualities of an individual who only think for himself or herself aiming for only ego, fame, name and power. 'Tamas Guna' is referring to the quality of an individual who are corrupted and driven by their personal interest, and willing to sacrifice anyone for his or her selfish goals. Based on the three gunas discussed, it was found that the definition of leadership communication provided by the Indians was consistent with 'Sattva Guna' which emphasized on the qualities of a leader as a person who possesses positive qualities, such as selflessness, aims to attain shared goals or vision, and works for the good of the people. The 'Sattva' attributes reflected by a leader is considered as an ethical characteristic that inspires followers can result in creation of positive perception among the follower. According to Kejriwal and Krishnan (2004), the 'Sattva Guna' proved to enhance transformational leadership that leads to change. In short, leadership communication could be defined as a process of showcasing selfless and ethical behaviour of a leader, motivating followers through effective communication skills with the follower, and practising inclusive leadership style which encourages feedback, suggestions and comments from followers that inspires them towards betterment.

Characteristics of Good Leadership Communication

The present study found that the ingredient for good leadership communication comprises of three main ideas which are consistent with the definition of leadership communication of Indians. The findings of the study indicated that the Indians emphasised on the positive characters of a leader, which includes selflessness, problem solver and ethical. A leader should communicate sincerely with the masses and work without expecting rewards, which means a leader should be able to communicate his or her ideas, vision, and policies in the interest and need of the masses or for the betterment of the society and nation. A selfless delivery, which aims for the betterment of people, will facilitate a leader to establish and maintain positive relationship with the followers. Through selfless delivery, a leader is expected to be able to identify and solve problems 
pertaining to the masses. The present study clearly found that a leader needs to identify the problem in the society and solve it accordingly. Regards to that, the Indians highlighted that a leader should not be corrupted and his or her leadership should be transparent. This is because the informants believe that a leader should lead by example, thus, it is important for leaders to be ethical including being transparent. Transparency is perceived as a very important component of ethics by Indians as it provides a space for the followers to judge the ethics of a leader. A study conducted by Sinha and Kaur (1992) has pointed out a few qualities that reflect 'Sattva Guna.' They are transparency, passion, and betterment. Thus, this study found that transparency element that was highlighted by informants is consistent with the 'Sattva Guna' in the Indian philosophy. It proved that transparency boost the confidence of followers towards a leader.

The second component of the characteristics of good leadership communication is leadership style. This study classified inclusiveness or participatory leadership and critical thinking as the components of good leadership communication characteristics. The study discovers that a leader should practice inclusiveness which means he or she should treat the community as one without neglecting any groups of the community. Regards to that, a leader needs to get feedback, suggestion and treat all communities equally. In order to practice inclusiveness, a leader needs to be critical, which means he or she should be analytic in evaluating issues arise. A leader must to able make a rationale decision based on his evaluation towards certain issues. The ancient literature BhagavadGita also has emphasised on social inclusiveness. In his writing on Bhagavad-Gita, Davis (2014) has highlighted the situation where 'Lord Krishna' was born in a tribe of cow herders which was a marginal community compared to Brahmins and Kshatriyas which reflects the social inclusiveness.

The third component is communication actions. It is important for a leader to produce positive outcomes out of the leadership communication process. Hence, a leader should be always fulfil his or her promises to the people. This is a very important quality to gain the confidence and trust of the people. Other than that, a leader must be able to control and manage different situations such as economy, social, and political issues which reflects the managerial skills of a leader. Therefore, in order to manage effectively, a leader should be an intellectual and a knowledgeable person. Lastly, this study also discovers that good leadership communication characteristics also involve selfless quality. This means a leader should prioritise his work commitment or duty for his people rather than his personal matters. To be selfless or work in the interest of the people, a leader needs a balanced emotional quotient. This is to ensure a leader makes a wise and ethical decision without any biases. As highlighted in the Bhagavad-Gita, one should perform their prescribed duties, be an example for others, and do for the good of others (Davis, 2014).

In summary, based on the Indians' cultural perspective, the characteristics of good leadership communication consist of the practice of participatory leadership style, positive ethics and effective communication of a leader which motivates, inspires and create confidence among people towards social change. Based on the idea established, this discussion found to be relevant to the Indians' religious philosophy that was emphasised in the Bhagavad-Gita whereby a leader encourages follower to give feedback, a leader must appear to be an effective communicator, courage and visionary, and practices a good ethics. These characteristics found to inspire and motivate followers to change both in terms of attitude and behaviour.

Jurnal The Messenger, Vol. 11, No. 1A, Special Issue on the School of Multimedia Technology and Communication Postgraduate Symposium, pp. 94-110 
This study discovered that Mahathir is a transformational leader who shows the culturally-specific leadership communication that inspire the Indian community in Malaysia towards social change. The Malaysian Hindus perceived Mahathir's leadership communication as culturally relevant to the Hindu Vedic philosophy. Therefore, although there are many negative issues pertaining to Mahathir and the Indian community, such as the marginalisation issue, the Malaysian Hindu still accept and influenced by Mahathir's leadership communication due to the cultural specific leadership communication characteristics.

This study concludes that Mahathir's leadership communication could be analysed through the seven characteristics of transformational leaders listed by Tichy and DeVanna (1990). Firstly, a transformational leader is a change agent. This situation could be associated with the character of Mahathir who was influential in changing the leadership of Tunku Abdul Rahman. Mahathir was critical towards the leadership of Tunku and boldly criticised policies implemented by Tunku. Another instance can be seen in Mahathir's policies that emphasised industrialisation more than agriculture in order to develop the society and nation which was viewed as a positive effort by the Indians.

Secondly, transformational leaders can be assumed as courageous people. Mahathir was perceived as a determined leader in implementing his policies for the betterment of people and the nation. For instance, although he faced many criticisms during the implementation of various policies, he was very firm in defending his policies. In order to gain people's support, he explained the rationales of his policies to the people and country. Specifically, during the economic crisis in 1998, Mahathir took a good decision which saved the country from great economic turmoil by stabilising Malaysian currency (Wain, 2012).

Thirdly, transformational leaders could be described as believers in people. A transformational leader believes that the people are capable to accomplish task given. As such, Mahathir empowered people through the visions he introduced. He urged people to work hard and achieve the visions he introduced. For instance, he emphasised on a set of ethics for civil servants by making amendments to General Orders. The guideline of a new code of ethics stressed more on moral values and attitude of the civil servants which includes cleanliness, efficiency, and trustworthiness. The code of ethics serves as a guideline for government officers to ensure the efficiency of the government sector. In Ahmad Atory (1997). Mahathir also encouraged creativity and innovation. Consistent with the idea, Mahathir introduced the Multimedia Super Corridor in 1992 to speed up the process of achieving the objectives of Vision 2020 and transformed Malaysia into a better nation. Thus, this programme emphasised creating a knowledge-based society which was aimed to cultivate creativity in people by providing wider access to information.

Next, transformational leaders are considered to be value driven. Consistent with the idea, Mahathir was perceived as a leader who fulfills his promises. For instance, Mahathir promised to build infrastructures such as Kuala Lumpur International Airport (KLIA), Kuala Lumpur City Centre (KLCC) and Putrajaya as a part of the modernisation process and he fulfilled the promises. He showed high determination and commitment to develop the society and nation.

Transformational leaders are lifelong learners which refer to the continuous selflearning and development. Mahathir, in his leadership era (1981-2003) appointed different panels of consultants to advise him on different matters. For instance, Mahathir appointed a panel of economic consultants to advise him on issues pertaining to the 
economy. This reflects the characteristic of lifelong learning of Mahathir, who was willing to listen and receive advises and recommendations on issues pertaining to the nation.

Transformational leaders also have the ability to deal with complexity, ambiguity, and uncertainty. Mahathir was perceived as a problem-solver. His policies and visions were aimed to solve issues pertaining to the society and nation. For instance, Mahathir has introduced the New Development Policy (NDP) to tackle socio-economic issues, specifically to sort economic imbalance between different ethnic groups which saw him as a problem-solver.

Lastly is visionary characteristic. Mahathir has introduced many visions for the people and nation, such as Vision 2020. Mahathir has established clear visions to transform the nation into a fully developed nation and communicated his expectations clearly to his people.

\section{Conclusion}

This study has provided the descriptions of the Hindus under the leadership of Mahathir. The present study revealed the Indians' conception on leadership communication. It provides an insight about the Indians' conception of leadership communication which could leads to the development of culture-specific leadership communication model. This study contributes to the body of knowledge, leadership communication, specifically from the minority followers' cultural perspective. It shows that follower is playing an active role in the leadership communication process; specifically in determining the characteristics of leadership communication. It was evident that culture (religion philosophy) of the Indians influences their attitude and behaviour towards leadership communication for social change.

This study also provides a new dimension to leadership communication from multicultural context, specifically leadership communication of a leader from the majority community and followers from the minority. It was important to investigate leadership communication relationship of the majority and minority because culture of communities in multi-racial countries like Malaysia plays an important role in creating differences between ethnic groups. It was found that Mahathir's leadership communication leads to social change among the Indians in Malaysia. Specifically, Mahathir's leadership communication attribute, intercultural communication sensitivity contribute to the effectiveness of his leadership communication. This attribute embraces the difference of his followers including the Indians. This has smoothened the leadership communication process between Mahathir and Malaysian Indians Interestingly, it was found that Mahathir's leadership communication is culturally-specific. It is consistent with the Indian Vedic philosophy of the Malaysian Hindus. Therefore, the Malaysian Hindus accept Mahathir's leadership communication which leads to social change among the Indians. Interestingly, it was discovered that culture played an important role in the leadership communication process between Mahathir and the Indian community in Malaysia.

\section{Acknowledgements}

The authors would like to place on record, the sense of gratitude to one and all, who directly or indirectly, have lent their hand in this study, especially to 15 informants consists of Indian political, non-governmental organisation and community representatives.

Jurnal The Messenger, Vol. 11, No. 1A, Special Issue on the School of Multimedia Technology and Communication Postgraduate Symposium, pp. 94-110 


\section{References}

Abu Bakar, H., \& McCann, R. M. (2014). Matters of demographic similarity and dissimilarity in supervision-subordinate relationship and workplace attitudes. International Journal of Intercultural Relations, 14, 1-16.

Abuznaid, S. (2005). Islam and management: What can be learned? Thunderbird International Business Review, 48(1), 125-139.

Ahmad Atory, H. (1997). The Leadership Factor in Administrative Reform in Malaysia, with a Specific Study on the Leadership of Dr. Mahathir Mohamad, Prime Minister of Malaysia. Pertanika J. Soc. Sci. \& Hum, 5(2), 103-123.

Amerson, R. (2011). Making a case for the case study method. Journal of Nursing Education, 50(8), 427-428. https://doi.org/10.3928.01484834-20110719-01

Andreouli, E. (2013). Identity and acculturation: The case of naturalized citizens in Britain. Culture \& Psychology, 19(2), Cult. Psychol. https://doi.org/10.1177/1354067X13478984

Ardichvili, A., \& Gasparishvili, A. (2001). Leadership profiles of managers in postcommunist countries: A comparative study. Leadership \& Organization Development Journal, 22(2), 62-69.

Asma, A. (1992). The influence of ethnic values on managerial practices in Malaysia. Malaysian Management Review, 27(1), 3-15.

Asma, A., \& Lim, L. (2001). Cultural dimension of Anglos, Australians and Malaysians. Malaysian Management Review, 36(2), 1-17.

Asma, A., \& Singh, S. (1992). Leading and motivating. In In A. Asma (Eds.) Understanding Malaysian workforce: Guideline for managers (pp. 33-48). Kuala Lumpur: Malaysian Institute of Management.

Ayman, R., \& Korabik, K. (2010). Leadership: Why gender and culture matter. American Psychologist, 65, 157-170.

Baharuddin, S. A. (2005). Making sense of national unity in Malaysia: 'Break down' versus 'break out' perspective. Kuala Lumpur: COLLA Research Group.

Bakar, H. A., Jian, G., \& Fairhurst, G. (2014). Where do I stand? The interaction of leadermember exchange and performance ratings. Asian Business \& Management, 13(2), $143-170$.

Barrett, D. (2014). Leadership communication (4th ed.). New York: McGraw-Hill Education.

Bass, B. M. (1990). Bass \& Stogdill's handbook of leadership (3rd ed.). New York: Free Press.

Bass, B. M. (1997). Does the transactional-transformational leadership paradigm transcend organizational and national boundaries? American Psychologist, 52(2), $130-139$.

Bass, B. M. (1999). Two decades of research and development in transformational leadership. European Journal of Work and Organizational Pyschology, 8(9-32).

Bass, B. M., \& Avolio, B. J. (1994). Improving organizational effectiveness through transformational leadership. Thousand Oaks: Sage.

Beekun, R. I., \& Badawi, J. A. (2005). Balancing ethical responsibility among multiple organizational stakeholders: The Islamic perspective. Journal of Business Ethics, 60, 131-145.

Bernard, R. H. (2012). Social research methods: Qualitative and quantitative approaches (2nd ed.). Thousand Oaks: Sage. 
Beyer, J. M. (1999). Taming and promoting charisma to change organizations. Leadership Quarterly, 10(2), 307-30.

Bhopal, M., \& Rowley, C. (2005). Ethnicity and a management issue and resources: Examples from Malaysia. Asia Pacific Business Review, 11(4), 553-574.

Bucic, T., Robinson, L., \& Ramburuth, P. (2010). Effects of leadership style on team learning. Journal of Workplace Learning, 22(4), 228-248. https://doi.org/10.1108/13665621011040680

Burns, J. M. (1978). Leadership. New York: Harper \& Row.

Chemers, M. M., \& Ayman, R. (1993). Leadership theory and research: Perspectives and directions. San Diego: Academic Press.

Chen, C. C., \& Van Velsor, E. (1996). New directions for research and practices in diversity leadership. Leadership Quarterly, 7(2), 285-302.

Chinmayanda, S. (2003). The Holy Geeta. Mumbai: Central Chinmaya Mission Trust.

Choong, L., \& Thomas, D. C. (1997). Leadership perceptions in the cross-cultural context: Pakeha and Pacific Islanders in New Zealand. Leadership Quarterly, 8(3), 275-293.

Dahles, H., \& Leng, L. W. (2014). Multicultural Organizations in Asia. Taylor \& Francis. https://doi.org/10.4324/9781315874159

Dahlia, Z. (2008). Cultural dimension among Malaysian employees. International Journal of Economics and Management, 2(2), 479-490.

Davis, R. H. (2014). The "Bhagavad-Gita": A biography. Princeton University Press.

Engardio, P., \& McGregor., J. (2006, October 30). Karma capitalism. Business Week.

Ensaria, N., \& Murphy, S. E. (1999). Cross-cultural variations in leadership perceptions and attribution of charisma to the leader. Organizational Behavior and Human Decision Processes, 92, 52-66. https://doi.org/10.1016/S0749-5978(03)00066-9.

Ergeneli, A., Gohar, R., \& Temirbekova, Z. (2007). Transformational leadership: Its relationship to culture value dimensions. International Journal of Intercultural Relations, 31(6), 703 - 724. https://doi.org/10.1016/j.ijintrel.2007.07.003

Fairhurst, G. T., \& Connaughton, S. L. (2014). Leadership: A communicative perspective. Leadership, 10(1), 7-35. Retrieved from http://dx.doi.org/10.1177/1742715013509396

Gardenswartz, L., Rowe, A., Digh, P., \& Bennett, B. (2003). The global diversity desk reference: Managing an international workforce. Somerset: Wiley Publishers.

Gordon, A., \& Yukl, G. (2004). The future of leadership research: Challenges and opportunities. German Journal of Human Resource Management, 18(3), 359-365. Retrieved

from https://www.gitasupersite.iitk.ac.in/srimad?ecsiva $=1 \&$ choose $=1 \& \&$ language $=$ ta $\&$ field_chapter_value $=17 \&$ field_nsutra_value $=18$

Graen, G. B. (2006). In the eye of the beholder: cross-cultural lesson in leadership from project GLOBE: A response viewed from the third culture bonding (TCB) model of cross-cultural leadership. The Academy of Management Perspective, 20(4), 95101.

Gudykunst, W. B., \& Nishida, T. (2001). Anxiety, uncertainty, and perceived effectiveness of communication across relationships and cultures. International Journal of Intercultural Relations, 25(1), 55-71.

Hall, R. J., \& Lord, R. G. (1995). Multi-level information processing explanations of followers leadership perceptions. Leadership Quarterly, 6, 265-287. Retrieved from

Jurnal The Messenger, Vol. 11, No. 1A, Special Issue on the School of Multimedia Technology and Communication Postgraduate Symposium, pp. 94-110 
https://www.gitasupersite.iitk.ac.in/srimad?ecsiva $=1 \&$ choose $=1 \& \&$ language $=$ ta $\&$ field_chapter_value $=17 \&$ field_nsutra_value $=18$

Hofstede, G. (1980). Motivation, leadership, and organization: Do American theories apply abroad? Organizational Dynamics, 9(1), 42-63. https://doi.org/10.1016/0090-2616(80)90013-3

Hofstede, G. (1983). National cultures in four dimensions: A research-based theory of cultural differences among nations. International Studies of Management \& Organizations, 13(1-2), 46-74.

Hofstede, G. (1991). Empirical models of cultural differences. Lisse: Swets \& Zeitlinger.

Hofstede, G. (2001). Culture's consequences: Comparing values, behaviors, institutions, and organizations across cultures. Thousand Oaks: Sage.

Hofstede, G., \& Hofstede, G. J. (2005). Cultures and organizations: Software of the mind (2nd ed.). New York: McGraw-Hill USA.

Hofstede, G., \& Minkov, M. (2010). Long-versus short-term orientation: New perspective. Asia Pacific Business Review, 16(4), 493-504.

House, R., \& Aditya, R. (1997). The social scientific study of leadership: Quo vadis? Journal of Management, 23(3), 409-474.

Jung, D., \& Avolio, B. (1999). Effects of leadership style and followers' cultural values on performance under different task structure conditions. Academy of Management Journal, 42, 208-218. https://doi.org/10.2307/257093

Kailasam, A. (2015). Indian identity and nation building in Malaysia. Kajian Malaysia, 33(1), 1-18. Retrieved from http://web.usm.my/km/33(1)2015/km33012015_01.pdf

Kanungo, R. N., \& Misra, S. (2004). Motivation, leadership, and human performance. In J. Pandey (Ed.). Psychology in India Revisited: Developments in the Discipline, 3, 309-341.

Kejriwal, A., \& Krishnan, V. R. (2004). The impact of Vedic worldview and Gunas on transformational leadership. Vikalpa, 29(1), 29-40.

Kennedy, J. C. (2002). Leadership in Malaysia: Traditional values, international outlook. Academy of Management Executive, 16(3), 15-25.

Khandwalla, P. N. (1990). Strategic developmental organizations: Some behavioural properties. In A. M. Jaeger \& R. N. Kanungo (Eds.), Management in developing countries (pp. 275-286). London: Routledge.

Krishnan, V. R. (2002). No TitleTransformational leadership and value system congruence. International Journal of Value-Based Management, 15(1), 19-33.

Leslie, J. B., \& Van Velsor, E. (1998). A cross national comparison of effective leadership and teamwork toward a specific global workforce. North Carolina: Center for creative leadership.

Lord, R. G., Brown, D. J., \& Freiberg, S. J. (1999). Understanding the dynamics of leadership: The role of follower self-concepts in the leader/follower relationship. Organizational Behavior and Human Decision Process, 78, 167-203.

Lynn-Sze, \& Ahmad, M. K. (2017). Confucian value-based leadership communication: A study on Tun Dr. Mahathir Mohamad. Malaysian Journal of Communication, 33(3), 140-156.

Lynn-Sze, J. C., Yusof, N., \& Ahmad, M. K. (2014). The relevance of Confucian values to Leadership communication. Malaysian Journal of Communication, 30, 129-144.

Markus, H. R., \& Kitayama, S. (1991). Culture and the self: Implications for cognition, emotion, and motivation. Psychological Review, 224-253. 
Means, G. P. (1991). Malaysian Politics: The Second Generation. Singapore: Oxford University Press.

Mhatre, K. H., \& Riggio, R. E. (2014). Charismatic and transformational leadership: present, and future. In The Oxford Handbook of Leadership and Organizations (pp. 221-240).

Mohd. Yusoff, Z. H., Roselina, A. S., \& Syed Azizi, W. (2002). No TLeadership style preferences of Malaysian managersitle. Malaysian Management Review, 37(1).

Muniapan, B. (2006). Can the Bhagavad-Gita be used as a manual for management development of Indian managers worldwide? In Asian Management: Convergence and Divergence. Tokyo: 5th Asia Academy of Management Conference.

Muniapan, B. (2007). Transformational leadership style demonstrated by Sri Rama in Valmiki Ramayana. International Journal of Indian Culture and Business Management, 1(1), 104-115.

Panda, A., \& Gupta, R. K. (2007). Call for developing indigenous organizational theories in India: Setting agenda for future. International Journal of Indian Culture and Business Management, 1(1/2), 205-243.

Paramita, S., \& Carissa, R. M. (2018). Inter-ethnic communication barriers in Pontianak City. Jurnal The Messenger, 10(1), 54-62.

Paramova, P., \& Blumberg, H. (2017). Cross cultural variation in political leadership styles. Europe's Journal of Psychology, 13(4), 749-766. https://doi.org/10.5964/ejop.v13i4.1412

Patton, M. Q. (2002). Qualitative research and evaluation methods (3rd ed.). Thousand Oaks: Sage.

Paulienè, R. (2012). Transforming leadership styles and knowledge sharing in a multicultural context. Transforming Leadership Styles and Knowledge Sharing in a Multicultural Context, 10(1), 91-109. https://doi.org/10.3846/bme.2012.08

Rarick, C. A., \& Nickerson, I. (2008). Expanding managerial consciousness: Leadership advice from the Bhagavad-Gita. Proceedings of the Academy of Organizational Culture, Communications and Conflict, 13(1).

Rusdi, O., \& Sivamurugan, P. (2006). Falsafah Pemikiran Politik Dr. Mahathir Mohamad. Pulau Pinang: Universiti Sains Malaysia.

Saad, S. (2012). Re-building the Concept of Nation Building in Malaysia. Science, 8(4), 115-123. https://doi.org/10.5539/ass.v8n4p115

Simbolon, D. (2012). Memahami komunikasi beda budaya antara suku Batak Toba dengan Suku Jawa di Kota Semarang (studi pada mahasiswa Suku Batak Toba dengen Suku Jawa di Universitas Semarang). Jurnal The Messenger, 4(1), 43-49.

Singh, N., \& Krishnan, V. R. (2007). Transformational leadership in India: Developing and validating a new scale using Grounded Theory approach. International Journal of Cross Cultural Management, 7(2), 219-236. https://doi.org/10.1177/1470595807079861

Singh, P., \& Bhandarker, A. (1990). Corporate success and Transformational Leadership. New Delhi: Wiley Eastern.

Sinha, A. K., \& Kaur, P. (1992). Dimension of Guna in Organizational Setting. Sage Journals, 17(3).

Smith, P. B., \& Peterson, M. F. (2002). Cross-cultural leadership. In M. J. Gannon \& L. K. Newman (Eds.), The Blackwell handbook of cross-cultural management (pp. 217-235). Oxford: Blackwell Publishers Ltd.

Taman, E., \& Krauss, S. E. (2017). Ethnic-related diversity engagement differences in

Jurnal The Messenger, Vol. 11, No. 1A, Special Issue on the School of Multimedia Technology and Communication Postgraduate Symposium, pp. 94-110 
intercultural sensitivity among Malaysian undergraduate students. International Journal of Adolesence and Youth, 22(2), 137-150.

Tayeb, M. (1997). Islamic revival in Asia and human resource management. Journal of Employee Relations, 19(4), 352-364.

Thomas, J., \& Harden, A. (2008). Methods for the thematic synthesis of qualitative research in systematic reviews. BMC Med Res Meth, 8, 45.

Tichy, N. M., \& DeVanna, M. A. (1990). The transformational leader. New York: Wiley.

Van Knippenberg, D., \& Sitkin, S. B. (2013). A critical assessment of charismatictransformational leadership research: Back to the drawing board? The Academy of Management Annals, 7(1), 1-60.

Wain, B. (2012). Malaysian maverick: Mahathir Mohamad in turbulent times. Journal of Social Issues in Southeast Asia, 20(1), 156-160. https://doi.org/10.1355/sj28-1g

Wibbeke, E. S. (2010). Global Business Leadership. Taylor \& Francis.

Yukl, G. (2006). Leadership in organizations (6th ed.). Englewood Cliffs, NJ: PrenticeHall. 